\title{
Examination of flexibility and sprint performance values of adolescent footballers
}

\author{
Bekir MENDES 1 , Tuncay ERCIN² ${ }^{2}$ Kenan UZUN ${ }^{3}$ \\ ${ }^{1}$ School of Physical Education and Sports, Gaziantep University, Gaziantep, Turkey. \\ ${ }^{2}$ Akkent School, Gaziantep, Turkey. \\ ${ }^{3}$ Mehmet Unsal School, Gaziantep, Turkey. \\ Address correspondence to B. Mentes, zeynimendes@hotmail.com).
}

\begin{abstract}
The flexibility is effective to provide an optimal body development appropriate to needs of sports branch and development of physical factors such as strength, speed and sport technique. The purpose of this study is to compare the flexibility and sprint performance values according to age and gender, the features of physical fitness performance of boys and girls who play football. Total of 172 volunteer's measurements were evaluated which consisted of 99 men footballer whose average

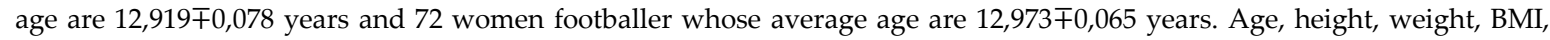
flexibility, $10 \mathrm{~m}$ and $20 \mathrm{~m}$ speed measurements of groups were taken. Multiple Regression Analysis was utilized for searching the relationships between flexibility and detected features. Formed by Stepwise variable selection method, the Multiple Regression Analysis was allowed to consist of statistically significant variables. Two sample T-test was used to compare gender in terms of average speed of $10 \mathrm{~m}$ and $20 \mathrm{~m} .10 \mathrm{~m}$ and $20 \mathrm{~m}$ sprint performance determined that the significant difference is in favor of the male players according to gender. The relationship between speed and flexibility was varied by gender. The significant relation was found between flexibility values and $10 \mathrm{~m}$ sprint performance values of male footballers $(\mathrm{P}=0,002)$, while the significant relation was found between flexibility values and $20 \mathrm{~m}$ sprint performance values of female footballers $(\mathrm{P}=0,009)$.In order to improve the sprint performance, which is a specific skill of football, flexibility of the muscles should be trained with a program at an early age.
\end{abstract}

Keywords: Adolescent footballer, flexibility, performance.

\section{INTRODUCTION}

The flexibility, which is also referred to range of motion in sporty meaning, is ability to move a single joint or group of joints at possible widest angle (23).

The flexibility is effective in providing an optimal development appropriate to needs of sport branch, physical factors such as the speed, strength and development of technique (11).

The flexibility, influenced by several factors including observed differences in the genetic structure of the joints, connective tissue elasticity, muscle viscosity, reciprocal muscle coordination, age, gender and body type (3). Flexibility in boys is fixed between ages 5-8, decreases until they are 1213 ages, remains fixed until they are 13-15 and then increases in the period up to 18 years. In girls, it remains fixed between 5-11 ages and then increases up to 14 years and reaches the plateau.
Girls are more flexible than men at all ages, and this difference is highest in adolescence. Increased flexibility in the girl comes up to 11 years of age in other words after about adolescence period when the length of the limb is increased.

Especially, the sudden extension of upper extremity long bone may affect the growing longer of the individual. The sudden increase in limb length may be the reason why men are taking lower value in the sit-and-reach test $(3,22)$.

In mass measurements, sit and reach test used as a rough flexibility indicator in flexibility measurements and in physical fitness test batteries related to health. Sit and reach test is often considered as a measure of the lower back and hamstring flexibility. Because of the relationship between low back pain and lower back and hamstring flexibility, physical fitness test batteries related to health are taken part in hypothesis frequently (23). 
By the reason of including simple and a lot of athletic ability, it was emphasized that the sit and reach test protocol provides a great convenience and advantages (10). The first phase of sprint performance begins to develop at the age of 8 in children; the second phase begins at the age of 12 in girls and between the ages of 12-15 in boys (20).

Footballer's ability to achieve high speed movements in football matches is important. Although high speed movements only contributing \%11 to the total distance, high speed running contribute directly to score a goal and keep the ball which are most important moves of the match (14). This study was planned to determine if the flexibility of adolescence footballers, between the ages of 12-14 years, change according to age and gender and this affects the sprint performance on flexibility.

\section{MATERIAL \& METHOD}

\section{Subjects}

A total of 200 footballers, consisted of100 girl and 100 boys were included in this study, which plays at youth setup of Gaziantep Amateur football League. 28 girls and 1 boy could not achieve the study. Total of 171 players' data as of 99 boys and 72 girl football players were evaluated. Ethics Committee approval was obtained for this study. All players informed about study plan and study purpose and they volunteered to participate with their own written certification.

\section{Data Collection}

The data were evaluated after once measured the age, height, weight, sporting age, flexibility with sit and reach test and sprint performance in $10 \mathrm{~m}$ and $20 \mathrm{~m}$ of the players participating in the study. To determine the morphological features of the subjects participating in the study; age, height and weight were determined. Sit-and-reach test is used to determine the flexibility; photocells were used to determine the 10 meter and 20 meter sprint performance.

\section{Age, Height, and Body Fat Index Calculation:}

When determining the age of the athlete in years, their height were measured with the height scale precision of $-0.01 \mathrm{~cm}$ while they are standing on scale with socks or bare feet and their body weight were measured with bascule precision of at 0.01 while they are standing with their shorts.

\section{Flexibility Measurement}

Flexibility measurements of the subjects were made with sit-and-reach test on flexibility table. The subjects put to test after warming up. The flexibility distance measured while subjects put their bare foot sole to the test table in sitting position without bending their knees, reaching forward and pushing the ruler forward and hold themselves 2 seconds at furthest stretching point $(17,24,21)$.

\section{Speed Measurement}

\section{0 meter sprint}

The subjects kept waiting in ready position after warming up 1 meter behind the starting photocells. After the start signal they ran at maximum speed along 10 meters. Measurement made with photocells put 10 meter distance from start and finish points. This run has been repeated twice and the best scores are registered

\section{0 meter sprint}

The subjects kept waiting in ready position after warming up 1 meter behind the starting photocells. After the start signal they ran at maximum speed along 20 meters. Measurement made with photocells put start and finish points of 20 meter distance. This run has been repeated twice and the best scores are registered.

\section{Analysis of data}

Multiple Regression Analysis utilized for searching the relationships between flexibility and detected features. Formed by Stepwise variable selection method, the Multiple Regression Analysis was allowed to consist of statistically significant variables. Multiple Regression Equations created for boys and girls are given in Table 2 and Table 3.Two sample T-test was used to compare gender in terms of average speed of $10 \mathrm{~m}$ and $20 \mathrm{~m}$ (Table 4). All statistical analysis produced by Minitab Statistical Packaged Software (ver. 17.0). 


\section{RESULTS}

Table 1. Gender informative statistics in terms of determined features.

\begin{tabular}{|c|c|c|c|c|c|}
\hline Variables & Gender & Average & SE Mean & Minimum & Maksimum \\
\hline \multirow[t]{2}{*}{ Age (years) } & $\mathrm{M}$ & 12.92 & 0.08 & 11.0 & 14.00 \\
\hline & W & 12.97 & 0.06 & 12.0 & 14.00 \\
\hline \multirow[t]{2}{*}{ Body Weight(kg) } & $\mathrm{M}$ & 42.52 & 0.86 & 30.00 & 86.00 \\
\hline & W & 41.59 & 1.06 & 30.00 & 90.00 \\
\hline \multirow[t]{2}{*}{ Height(cm) } & M & 1.55 & 0.01 & 1.44 & 1.72 \\
\hline & $\mathrm{W}$ & 1.57 & 0.01 & 1.44 & 1.72 \\
\hline \multirow[t]{2}{*}{$\mathrm{BFI}\left(\mathrm{kg} /(\mathrm{boy})^{2}\right.$} & $\mathrm{M}$ & 17.72 & 0.25 & 12.82 & 26.84 \\
\hline & W & 16.87 & 0.33 & 13.15 & 32.27 \\
\hline \multirow[t]{2}{*}{ Flexibility $(\mathrm{cm})$} & $\mathrm{M}$ & 3.10 & 0.49 & -12.00 & 16.00 \\
\hline & W & 4.85 & 0.48 & -7.30 & 13.20 \\
\hline \multirow[t]{2}{*}{10 m speed(sec) } & $\mathrm{M}$ & 1.86 & 0.01 & 1.35 & 2.12 \\
\hline & W & 2.02 & 0.02 & 1.72 & 2.47 \\
\hline \multirow[t]{2}{*}{20 m speed(sec) } & $\mathrm{M}$ & 3.55 & 0.03 & 2.94 & 4.12 \\
\hline & W & 3.82 & 0.03 & 3.03 & 4.40 \\
\hline
\end{tabular}

Table 2. Regression Analysis Results for Male.

\begin{tabular}{lcccc}
\hline Variables & Coefficient of part Regression & Standard Error & t-values & P-values \\
\hline \multirow{2}{*}{ Stable } & 22.01 & 5.95 & 3.70 & 0.000 \\
10 m speed & -10.17 & 3.19 & -3.19 & 0.002 \\
& & & & \\
\hline Regression Equality: Flexibility=22.01-(10.17) $10 \mathrm{~m}$ speed & $\mathrm{R}^{2}=12.68 \%$
\end{tabular}

Table 3. Regression analysis results for female.

\begin{tabular}{lcccc}
\hline Variables & Coefficient of part Regression & Standard Error & t-values & P-values \\
\hline & & & & \\
Stable & -13.36 & 6.82 & -1.96 & 0.054 \\
$20 \mathrm{~m}$ speed & 4.76 & 1.78 & 2.68 & 0.009 \\
& & & \\
\hline Regresyon Equality: Flexibility=-13.36+(4.76) $20 \mathrm{~m}$ speed & $\mathrm{R}^{2}=11.77 \%$
\end{tabular}

Table 4. Comparison of $10 \mathrm{~m}$ and $20 \mathrm{~m}$ speed averages in terms of gender.

\begin{tabular}{lcccc}
\hline Variables & $\mathrm{N}$ & Mean \pm SD & $\mathrm{t}$ & $\mathrm{p}$ \\
\hline & & & & \\
$10 \mathrm{~m}$ speed & 99 & $1.860 \pm 0.015$ & -6.76 & 0.000 \\
$20 \mathrm{~m}$ speed & 73 & $2.023 \pm 0.019$ & -6.43 & 0.000 \\
& & & \\
\hline
\end{tabular}

\section{DISCUSSION}

Flexibility and sprint performance values in adolescent players examined in this study and findings compared with the literature. Applied in physical fitness test batteries, sit-and-reach test protocol is used to determine the flexibility of children; photocells were used to determine the 10 meter and 20 meter sprint performance.

In this study, the men's sprint performance values in $10 \mathrm{~m}$ and $20 \mathrm{~m}$ were determined to be higher than female footballers sprint performance while the flexibility performance of females is higher than males in applied sit-and-reach test in term of gender (Table 1).

In recent years studies focused on sprint performance tests for talented young players and beneficial results were obtained for the performance in these procedures.

In this study, $10 \mathrm{~m}$ average sprint value determined as $1.86 \mathrm{secand} 2.02 \mathrm{sec}$ in male and female children footballers, while $10 \mathrm{~m}$ average sprint value determined as $3.54 \mathrm{sec}$ in boys and $3.84 \mathrm{sec}$ in girls (Table 1 ). 
Speed is the most frequently used action in the way of goal (9). The speed feature makes progress with age in girls and boys (18). Reporting that the speed performance increased with the increasing strength and related to the age, Eniseler et al. ranged the performance values of 12-14 age group of children such as; $10 \mathrm{~m}$ sprint value of 12 years old children is $1.95 \mathrm{sec}$. and $20 \mathrm{~m}$ sprint value is $3.52 \mathrm{sec}, 10 \mathrm{~m}$ sprint value of 13 years old children is $1.91 \mathrm{sec}$ and $20 \mathrm{~m}$ sprint value is 3,44 sec. , $10 \mathrm{~m}$ sprint value of 14 years old children is $1,81 \mathrm{sec}$. and $20 \mathrm{~m}$ sprint value is $3,26 \mathrm{sec}$. (4).

In different studies done with young footballers, Woods et al. (2) reported the $10 \mathrm{~m}$ sprint values as $1.83 \pm 0.06 \mathrm{sec}$. and $20 \mathrm{~m}$ sprint values as $3.09 \pm 0.10 \mathrm{sec}$. Miranda et al. (19) reported $10 \mathrm{~m}$ sprint values as $2.15 \pm 0.13 \mathrm{sec}$. Kumartasli et al. (13) reported $20 \mathrm{~m}$ sprint values as $4.99 \pm 0.73 \mathrm{sec}$ in $10-12$ age group footballers. In another study Kulak et al. (12) measured the effect of 14-week mental training to some motor features and reported that average value of $20 \mathrm{~m}$ sprint performance of 10-12 age group footballers is $3.57 \pm 0.21 \mathrm{sec}$.

In the study done for ability selection and project of guidance to sport, Arabaci et al. (1) reported that average $20 \mathrm{~m}$ sprint value is $3.92 \mathrm{sec}$. in girls, $3.70 \mathrm{sec}$. in boys; Ozdemir et al. (16) reported that $20 \mathrm{~m}$ sprint time of young footballers, who are in the u14 age group, is $3.26 \pm 0.13 \mathrm{sec}$.

As a result of t-test done to compare the difference between genders in terms of sprint performance, both $10 \mathrm{~m}$ and $20 \mathrm{~m}$ sprint performance determined that the significant difference is in favor of the male players according to gender. These values can be different from our findings because of the measurement period and different trained levels of children.

Flexibility is important for footballers in terms of improving mobility, coordination and ameliorating the competence about football skills and prevention of disability and most suitable period is 11-13 years for body-building (7).

Flexibility can be changed according to age, gender, trained, sport age and performance of the footballers, so it must be considered with regard to performance improvement in adolescent football.

Flexibility is an important factor for athletic performance (5). Garcia-Pinillos et al. emphasized that there is a relationship between hamstring flexibility, sprint performance and strength in male footballers at the age of 14-18(6). As a result of similar 12 week study done with young footballers, it was determined that $5 \mathrm{~m}, 10 \mathrm{~m}$ and 20 $\mathrm{m}$ sprint performances affected the development of flexibility (15). In the examination of relationship between static flexibility training and physical fitness components, it was reported that flexibility is effective in improving explosiveness and agility performance in young professional football players (8).

It is observed in the studies that strength and flexibility, agility and speed relationship is strong. Although the flexibility of girls is stronger than boys in our study, $10 \mathrm{~m}$ and $20 \mathrm{~m}$ sprint performance is in favor of boys and this can be explained by being stronger. On the other hand the relationship between flexibility and sprint performance in adolescent footballers examined and the relationship between speed and flexibility varied by gender. The significant relation was found between flexibility values and $10 \mathrm{~m}$ sprint performance values of male footballers $(\mathrm{P}=0,002)$, while the significant relation was found between flexibility values and $20 \mathrm{~m}$ sprint performance values of girl footballers $(\mathrm{P}=0,009)$.

In consequence of our study as it can be understood from the literature, flexibility decreases with age and this influences the sprint performance negatively and must be trained in every training department, in order to improve the sprint performance, which is a specific skill of football, flexibility of the muscles should be trained with a program at an early age.

\section{REFERENCE}

1. Arabaci R, Koparan S, Ozturk F, Akin M. Olimpiyatlar İcin Sporda Yetenek Secimi ve Spora Yonlendirme Projesi İI. Asama Sonuclarinin İncelenmesi (Bursa Ornegi). e - Journol of New World Sciences Academy, 2008, 3, (2), B0019, 86-98.

2. C Woods, Raynor A, Bruce L, McDonald Z, Collier N. Predicting playing status in junior Australian Football using physical and anthropometric parameters. Journal of Science and Medicine in Sport, 2015; 18(2): 225-229.

3. Duzgun I, Baltaci G. Duzenli Spor Yapan ve Yapmayan Adolesanlarda Esneklik Test Sonuclarinin Yas ve Cinsiyete Bagli Degisimi. Fizyoterapi Rehabilitasyon. 2009; 20(3):184189.

4. Eniseler N. Çocuk ve Gençlerde Futbol Antrenmanı. İstanbul: TFF FGM Futbol Egitim Yayinlari, Sayı: 8, 2009.

5. Favero JP, Midgley AW, Bentley DJ. Effects of an acute bout of static stretching on $40 \mathrm{~m}$ sprint performance, İnfluence of baseline flexibility. Research in Sports Medicine, 2009; 17(1): 50-60. 
6. Garcia-Pinillos A, Ruiz-Ariza R, Moreno DC, LatorreRoman PA. Impact of limited hamstring flexibility on vertical jump, kicking speed, sprint, and agility in young football players. Journal of Sports Sciences, 2015: 33(12): 1293-1297.

7. Guler D, Kayapinar FC, Pepe K, Yalciner M. Futbol sampiyonasina katilan cocuklarin fiziksel, fizyolojik, teknik ozellikleri ve performanslarini etkileyen faktorler. Genel Tip Dergisi 2010; 20(2): 43-49.

8. Hadjicharalambous M. The effects of regular supplementary flexibility training on physical fitness performance of young high-level soccer players. J Sports Med Phys Fitness, 2015 May 25. [Epub ahead of print]

9. Haugen T, Tonnessen E, Hisdal J, Seiler S. The role and development of sprinting speed in soccer. Int $\mathrm{J}$ Sports Physiol Perform, 2014; 9(3): 432-41.

10. Heyward VH. Advanced Fitness assessment and Exercise Prescription. Fiffth Edition, USA: Human Kinetics, 2006.

11. Kocak M, Akkoyunlu Y, Taskin H. 16 - 18 yas grubu futbolcularda masajin esneklik uzerine etkisi. SPORMETRE Beden Egitimi ve Spor Bilimleri Dergisi, 2005; 3(3): 105-109.

12. Kulak A, Kerkez FI, Aktas Y. Zihinsel antrenman programinin 10-12 yas futbolcularda bazi motor ozelliklere etkisi. Spor Bilimleri Dergisi, 2011; 22(3): 104-114.

13. Kumartasli M, Topuz R, Dagdelen S. 10-12 yas grubu futbolcularin motorik performansinin degerlendirilmesi. International Journal of Science Culture and Sport. 2014; SI(2): 101-113

14. Little T, Willams AG. Specifity of acceleration, maximal speed and agility in professional soccer players. Journal of Strength and Conditioning Research, 2005; 19(1): 76- 78.

15. Milanovic Z, Sporis G, Trajkovic N, Sekulic D, James N Vuckovic G. Does SAQ training improve the speed and flexibility of young soccer players? A randomized controlled trial. Hum Mov Sci, 2014; 38: 197-208.

16. Ozdemir FM, Yilmaz A, İsler AK. Genc futbolcularda tekrarli sprint performansinin yasa gore incelenmesi. Spor Bilimleri Dergisi, 2014; 25(1): 1-10.

17. Ozer K. Fiziksel Uygunluk. Ankara: Nobel Yayin Dagitim, 2001.

18. Papaiakovou G, Giannakos A, Michailidis C, Patikas D, Bassa E, Kalopisis V, Ninkolaos A. The effect of chronological age and gender on the development of sprint performance during childhood and puberty. Journal of Strength and Conditioning Research, 2009; 23(9): 2568-2573.

19. Miranda REEPC, Antunes HKM, Pauli JR, Puggina EF, da Silva ASR. Effects of 10-week soccer training program on anthropometric, psychological, technical skills and specific performance parameters in youth soccer players. Science \& Sports, 2013; 28: 81-87.

20. Reilly T, Bangsbo J, Franks A. Anthropometric and physiological predispositions for elite soccer. Journal of Sports Sciences, 2000; 18: $669-683$

21. Saka T, Yildiz Y, Tekbas OF, Aydin T. Genc erkeklerde spor okulu egitim programinin bazi antropometrik ve fonksiyonel testler uzerine etkisi. Nigde Universitesi Beden Egitimi ve Spor Bilimleri Dergisi, 2008; 2(1): 1-8.

22. Saygin O, Zorba E. Fiziksel Aktivite ve Fiziksel Uygunluk. İnceler Ofset, 2009.

23. Sahiner I, Balci SS. Comparision of different sit and reach tests in children. Nigde University Journal of Physical Education and Sport Sciences, 2010; 4(1).

24. Tamer K. Sporda Fiziksel-Fizyolojik Performansin Olculmesi ve Degerlendirilmesi. Ankara: Bagirgan Yayinevi, 2000. 